\title{
ENVIRONMENTALLY INDUCED CHANGES OF SEX EXPRESSION IN ATRIPLEX CANESCENS
}

\author{
E. DURANT MCARTHUR \\ Intermountain Forest and Range Experiment Station, Forest Service, \\ U.S. Department of Agriculture, Ogden, Utah 84401*
}

Received 16.ix.76

\begin{abstract}
SUMmary
The western North American shrub Atriplex canescens is predominantly dioecious, but most populations contain some monoecious individuals. A tetraploid half-sib family consisting of 665 individuals was evaluated annually for floral phenotype (sex expression) from 1972-75. The autumn/winter of 1972-73 started out mild and wet and then turned unusually cold. The halfsib family expressed a very different sex ratio in the 1973 growing season than in the three other years. A sex-determining mechanism is proposed of XXXX for pistillate plants, XXYY for staminate plants, and XXXY for monoecious plants and those that vacillate among floral phenotypes from year to year.
\end{abstract}

\section{INTRODUCTION}

Atriplex canescens (Pursh) Nutt. is a widely occurring western North American shrub. In addition to being an important part of the vegetation, it is a valuable forage plant for both wildlife and livestock and is proving to be useful as cover on disturbed sites such as mine spoils (Hall and Clements, 1923; Plummer et al., 1966; Aldon, 1973; Blauer et al., 1976).

The species is usually dioecious, but workers have found monoecious plants here and there. Hall and Clements (1923) suggested that $A$. canescens is rarely monoecious and Hanson (1962) reported that the overall frequency of monoecious plants is about 3 per cent. On the other hand, Stutz et al. (1975) contended that monoecism is common in most populations. Stutz et al. (1975) discovered an unusual gigas population which grows only on the Little Sahara Sand Dunes in central Utah. This population is entirely dioecious and diploid $(2 n=18)$; all other $A$. canescens populations which have been cytologically studied (about 75) are tetraploid (Bassett and Crompton, 1971 ; Stutz et al., 1975; E. D. McArthur, unpublished).

We initiated a study of the year-to-year trait constancy of a half-sib family of $A$. canescens to identify superior plants for breeding and selection purposes (McArthur and Plummer, 1974). Along with other traits, the floral phenotype of each plant in this family has been scored annually since 1972. When the floral phenotypic ratio changed dramatically after the 1972-73 winter, we looked for a cause.

\section{Materials And methods}

A tetraploid half-sib family of $A$. canescens was established during the early autumn of 1968 by transplanting seedlings to a 0.14-ha site at the Snow Field Station in Ephraim, Utah. The transplants were placed in

* Located at the Intermountain Station's Shrub Sciences Laboratory, Provo, Utah 84601. $38 / 1-G$ 
rows at a uniform spacing of $1.22 \mathrm{~m}$. The plot was irrigated initially to facilitate plant establishment, but has since received no cultural care other than periodic weed removal. The seed that produced the family was collected from a single pistillate plant in a plantation grown from seed collected in the Carson National Forest near Canjilon, New Mexico. In 1972, the 665 surviving half-sibs were tagged. Each year (1972-75) during September, the plants were individually evaluated for several morphological traits including the floral phenotype:

$\phi=$ pistillate $; \hat{o}=$ staminate $[\hat{q}, \hat{\jmath}]=$ monoecious $; 0=$ no flowering.

\section{Results AND DISGUSSION}

The half-sib family showed a preponderance of pistillate plants; the approximate ratio of 55 $q: 34 \hat{\delta}: 7[0, \delta]: 4 \bigcirc$ is generally consistent for all years except 1973 (table 1). Where data are available, this ratio is similar to that of stock related to the half-sib family (table 2). A sample of the parental population was scored for floral phenotype in 1972 and 1974, but not in 1973, unfortunately.

TABLE 1

Floral phenotypes (1972-1975) in a half-sib family of A. canescens

\begin{tabular}{|c|c|c|c|c|c|c|}
\hline \multirow[b]{2}{*}{ Year } & \multicolumn{5}{|c|}{ Per cent } & \multirow[b]{2}{*}{ Population } \\
\hline & 古 & 0 & {$[R, 3]$} & 0 & Dead* & \\
\hline 1972 & $55 \cdot 9$ & $34 \cdot 3$ & $5 \cdot 1$ & $4 \cdot 7$ & - & 665 \\
\hline 1973 & $37 \cdot 9$ & $37 \cdot 4$ & $13 \cdot 5$ & $11 \cdot 3$ & $7 \cdot 4$ & 616 \\
\hline 1974 & $53 \cdot 9$ & $34 \cdot 5$ & $8 \cdot 7$ & $3 \cdot 2$ & $2 \cdot 4$ & $599+$ \\
\hline 1975 & $54 \cdot 5$ & $34 \cdot 3$ & $7 \cdot 1$ & $4 \cdot 0$ & $2 \cdot 5$ & $579 \dagger$ \\
\hline
\end{tabular}

* Based on number of live plants the prior growing season. No inventory was made in 1971.

$\dagger$ These numbers reflect reduction in population size for pathological evaluations. Two plants were excavated prior to the 1974 evaluations and five plants prior to the 1975 evaluations. (D. L. Nelson, personal communication.)

TABLe 2

Floral phenotypes exhibited by plants relaled to the half-sib family

\begin{tabular}{|c|c|c|c|}
\hline \multirow{2}{*}{$\begin{array}{c}\text { Floral } \\
\text { phenotype }\end{array}$} & \multicolumn{2}{|c|}{$\begin{array}{c}\text { Sample of } \\
\text { parental population* }\end{array}$} & \multirow{2}{*}{$\begin{array}{l}\text { Progeny from open } \\
\text { pollenation of } \\
\text { parental population } \dagger \\
1972\end{array}$} \\
\hline & 1972 & 1974 & \\
\hline & \multicolumn{3}{|c|}{ Per cent } \\
\hline 9 & $55 \cdot 6$ & $50 \cdot 0$ & $55 \cdot 7$ \\
\hline 0 & $31 \cdot 4$ & $26 \cdot 7$ & $37 \cdot 0$ \\
\hline$[0, \%]$ & $11 \cdot 7$ & $14 \cdot 1$ & $7 \cdot 3$ \\
\hline 0 & 1.5 & $7 \cdot 0$ & - \\
\hline
\end{tabular}

* $\mathrm{N}=76$. Plants were systematically tagged (every fourth plant in random rows in 1972). The same plants were scored each year.

$\dagger \mathrm{N}=1840$. Data from Van Epps (1975). 
That year, the floral phenotypic ratio of the half-sib family was substantially different from other years. The most striking change was the reduced number of pistillate plants. Pistillate plants would require more energy in summer-long seed production than staminate plants would for spring pollen production. There is some evidence of differential physiology in sexes of woody Atriplexes. Stark (1970) reported a lower internal water stress for staminate plants of $A$. hymenelytra than for pistillate plants. However, her data for the different sexes of $A$. canescens was equivocal. Detailed floral phenotype or sex changes for 1973 are indicated in table 3.

The autumn and winter of 1972-73 were successful for woody plants in the Utah area (E. A. Richardson, Utah State Climatologist, personal communication). Many ornamental and fruit trees were killed, others died

TABLE 3

Changes of floral phenotypes in the half-sib family from 1972 to 1973

\begin{tabular}{|c|c|c|c|}
\hline $\begin{array}{l}\text { Type of } \\
\text { change }\end{array}$ & $\begin{array}{l}\text { Number of } \\
\text { plants }\end{array}$ & $\begin{array}{l}\text { Reciprocal change } \\
\text { (number of plants) }\end{array}$ & $\begin{array}{r}\text { Net cha } \\
\text { (number of }\end{array}$ \\
\hline 우 $\rightarrow 0^{*}$ & 28 & I & 27 \\
\hline 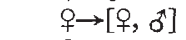 & 58 & 7 & 51 \\
\hline$q \rightarrow 0$ & 36 & 4 & 32 \\
\hline 을 Dead & 29 & 一 & 29 \\
\hline$\sigma \rightarrow[+9,0]$ & II & 10 & \\
\hline$\sigma \rightarrow 0$ & 22 & 12 & 10 \\
\hline$\vec{b} \rightarrow$ Dead & 14 & - & 1 \\
\hline$\left[\right.$ 우 $\left.\sigma^{-}\right] \rightarrow 0$ & 5 & 2 & \\
\hline$\left[0, \sigma^{*}\right] \rightarrow$ Dead & 0 & - & \\
\hline $\mathrm{O} \rightarrow$ Dead & 6 & - & \\
\hline Totals & 209 & 36 & 173 \\
\hline
\end{tabular}

No change: 420

back to their bases or root stocks. Van Epps (1975) noted considerable mortality in several transplanted accessions of $A$. canescens at two locations in central Utah. In general, the mortality was higher for those which originated in milder climates. The mortality and die-back in the half-sib family illustrate the severity of the 1972-73 winter (table 1).

That year was characterised by a mild, damp autumn followed by a very cold winter (table 4$)$. The October mean minimum $\left(1 \cdot 6^{\circ} \mathrm{C}\right)$ was the highest and the November mean minimum $\left(-4.7^{\circ} \mathrm{C}\right)$ the third-highest since records were begun at the Snow Field Station in 1959. Precipitation for September through November 1972 , totalled $131.1 \mathrm{~mm}$, the highest total for those 3 months on record and nearly twice the 17 -year mean of $78.5 \mathrm{~mm}$ for that portion of the year. These conditions apparently did not provide the plants with a suitable cold-hardening period that would have helped them weather the extremely cold temperatures of early December 1972 (AshwoodSmith, 1970). The first half of December 1972 was the coldest measured at the Snow Field Station (minimum mean $=-20 \cdot 4^{\circ} \mathrm{C}$, table 4 ). Four days had temperatures below $-25^{\circ} \mathrm{C}$.

The stressful winter killed many plants (table l), killed back others (most of the $\bigcirc$ plants in table 1 ), and apparently induced many to change sex (table 3). Environmental conditions have been implicated in sex changes 
TABLE 4

Mean monthly minimum temperature and precipitation at the Snow Field Station, Ephraim, Utah

Month and half-month periods

\begin{tabular}{|c|c|c|c|c|c|c|}
\hline & September & October & November & $\begin{array}{c}\text { December } \\
1-15\end{array}$ & $\begin{array}{c}\text { December } \\
16-31\end{array}$ & January \\
\hline Years & \multicolumn{6}{|c|}{ Mean minimum temperatures $\left({ }^{\circ} \mathrm{C}\right)$} \\
\hline $1959-75$ & $3 \cdot 2$ & -1.9 & $-6 \cdot 8$ & $-9 \cdot 2$ & $-12 \cdot 9$ & $-14 \cdot 2$ \\
\hline $1971-72$ & $1 \cdot 5$ & $-1 \cdot 4$ & -6.6 & $-16 \cdot 3$ & $-14 \cdot 3$ & $-11 \cdot 1$ \\
\hline $1972-73$ & $4 \cdot 2$ & 1.6 & $-4 \cdot 7$ & $-20 \cdot 4$ & $-10 \cdot 9$ & $-18 \cdot 2$ \\
\hline $1973-74$ & $2 \cdot 4$ & $-2 \cdot 0$ & $-6 \cdot 0$ & $-9 \cdot 6$ & $-9 \cdot 5$ & $-14 \cdot 5$ \\
\hline \multirow[t]{2}{*}{$1974-75$} & $2 \cdot 8$ & $0 \cdot 0$ & $-6 \cdot 0$ & $-10 \cdot 8$ & $-15 \cdot 2$ & $-15 \cdot 4$ \\
\hline & \multicolumn{6}{|c|}{ Mean precipitation $(\mathrm{mm})$} \\
\hline $1959-7.5$ & 295 & 264 & 226 & & & 221 \\
\hline $1971-72$ & 216 & 622 & 165 & & & 114 \\
\hline $1972-73$ & 406 & 610 & 305 & & & 203 \\
\hline $1973-74$ & 145 & 135 & 335 & & & 470 \\
\hline $1974-75$ & 13 & 305 & 140 & & & 203 \\
\hline
\end{tabular}

in several plant groups; for example, two species of Arisaema (Schaffner, 1922) and Spinacia oleracea (Quagliotti, 1972). Zuk (1970) reported that he had observed Urtica dioica plants that change sex from year to year. Sex expression is some monoecious and dioecious plant groups is influenced by plant hormones (Amchem Products, Inc., 1971; de Wilde, 1971; Rudich et al., 1972).

Although most of the sex reversals occurred only 1 year during the 4 years of record, 61 plants changed sex in more than 1 year (table 5). This instability would seem to indicate a sensitive sex-determining mechanism for some plants.

The method of sex determination in A. canescens is unknown. Chromosomes are small (about $1 \mu \mathrm{m}$ long) and difficult to identify separately. No aneuploidy has been found so the tripartite sex chromosome mechanism of

TABLE 5

Number of plants in the half-sib family that changed floral phenotypes (1972-75)*

\begin{tabular}{|c|c|c|c|c|c|}
\hline \multicolumn{6}{|c|}{ Plants that changed only one year $\uparrow$} \\
\hline \multirow[b]{2}{*}{$\begin{array}{l}\text { Type of } \\
\text { change }\end{array}$} & \multicolumn{4}{|c|}{ Year } & \multirow[b]{2}{*}{ Tota } \\
\hline & 1972 & 1973 & 1974 & 1975 & \\
\hline$q \rightarrow \infty$ & 0 & 16 & 0 & 1 & 17 \\
\hline 우 $\rightarrow\left[\right.$ ㅇ, $\left.0^{-1}\right]$ & 5 & 44 & 4 & 2 & 55 \\
\hline $0 \rightarrow+9$ & 4 & 0 & 1 & 1 & 6 \\
\hline$\delta^{*} \rightarrow[9,0)$ & 2 & 7 & 4 & 0 & 13 \\
\hline$[0,0] \rightarrow$ o & 7 & 2 & 0 & 1 & 10 \\
\hline$\left[0,0^{\star}\right] \rightarrow 0^{\star}$ & 1 & 4 & 1 & 0 & 6 \\
\hline & 19 & 73 & 10 & 5 & 107 \\
\hline
\end{tabular}

\begin{tabular}{|c|c|}
\hline \multicolumn{2}{|c|}{$\begin{array}{l}\text { Plants that changed } \\
\text { more than one year }\end{array}$} \\
\hline $\begin{array}{l}\text { Type of } \\
\text { change }\end{array}$ & $\begin{array}{l}\text { Number of } \\
\text { plants }\end{array}$ \\
\hline Q $\leftrightarrow 0^{*}$ & 1 \\
\hline 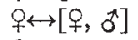 & 15 \\
\hline$\phi \leftrightarrow 0$ & 6 \\
\hline$d^{x} \rightarrow\left[q, 0^{x}\right]$ & 5 \\
\hline$d \leftrightarrow 0$ & 4 \\
\hline Others & 30 \\
\hline & $\overline{61}$ \\
\hline
\end{tabular}

* Excludes plants that died before 1975 evaluations.

$\dagger$ Excludes plants that missed flowering one year, but were otherwise constant in floral phenotype.

$\ddagger$ Includes all three state changes. 
some Rumex species (Löve, 1969; Smith, 1969), a form of which has been suggested for Atriplex hymenelytra (Billings, 1934), does not fit for A. canescens. Stutz et al. (1975) proposed a heterogametic XX-XY mechanism for the only known diploid. This explanation fits well for the diploid since only dioecious plants are known to occur. Tetraploid populations would presumably have at least four chromosomes each with at least one locus involved in sex determination. For simplicity, assume that a zygote must have two or more X's to live. Westergaard (1958) reported all known diploid dioecious plants that lack an $\mathrm{X}$ are inviable. Three viable combinations are then possible: XXXX, XXXY, XXYY. I propose that these states could well explain the pistillate, monoecious, and staminate phenotypes of A. canescens. The XXXY state could be pistillate, staminate, or both and could express the different phenotypes under various environmental conditions.

My interpretation explains constant sex expression of many plants - the XXXX's and XXYY's. Seventy per cent of the half-sib family plants were constant in floral phenotype over the 4-year period. The half-sib family and its related stock have an approximate phenotypic ratio of $55: 10: 35$, 우: [우 0$]$ : 0 (tables 1,2 ). This similarity in phenotypic ratio may be fortuitous. The genotypes of the pistillate parent and proximate staminate plants are unknown. If the genotypic frequency is assumed to be 20 per cent XXXX, 55 per cent XXXY, and 25 per cent XXYY with most of the XXXX expressing the $ᄋ$ phenotype and the remainder expressing equally the $[ㅇ, 0]$ and $\delta$ phenotypes, the population can be assumed to be near equilibrium (fig. 1 , table 6). The frequency after one generation (table 6) is slightly different than the beginning frequency $(0 \cdot 198: 0.516$ : 0.287 versus $0.200: 0.550: 0.250$ ), but could be brought into line with

\section{TABLE 6}

Mating combinations and subsequent progeny for tetraploid A. canescens

Mating combinations

\begin{tabular}{|c|c|}
\hline $\begin{array}{l}\text { Presumed } \\
\text { genotypes }\end{array}$ & Frequencies* \\
\hline $\mathrm{XXXX} \cdot \mathrm{XXXY}$ & 0.125 \\
\hline $\mathrm{XXXX} \cdot \mathrm{XXYY}$ & $0 \cdot 208$ \\
\hline
\end{tabular}

$\mathrm{XXXY} \cdot \mathrm{XXXY} \quad 0 \cdot 250$

Progency frequencies

$\begin{array}{lccc} & \text { XXXX } & 0.250 \\ \text { XXXY } & 0.500 \\ \text { XXXY } & & 0.250 \\ & & \text { XXXX } & 0.091 \\ \text { XXXY } & 0.455 \\ & 0.417 & \text { XXYY } & 0.455 \\ & & \text { XYYY } & \text { Not viable }\end{array}$

Summary of Progeny Frequency: 0.198 XXXX

$0.516 \mathrm{XXXY}$

$0 \cdot 287 \mathrm{XXYY}$

* Mating frequencies were calculated by assuming random mating of the sexual genotypes of fig. 1, the XXXY $\left[\right.$, $\left.\sigma^{*}\right]$ were apportioned equally to XXXY ${ }^{*}$ and XXXY , for example, $\mathrm{XXXX} \cdot \mathrm{XXXY}=0.333 \times 0.375=0 \cdot 125$. 

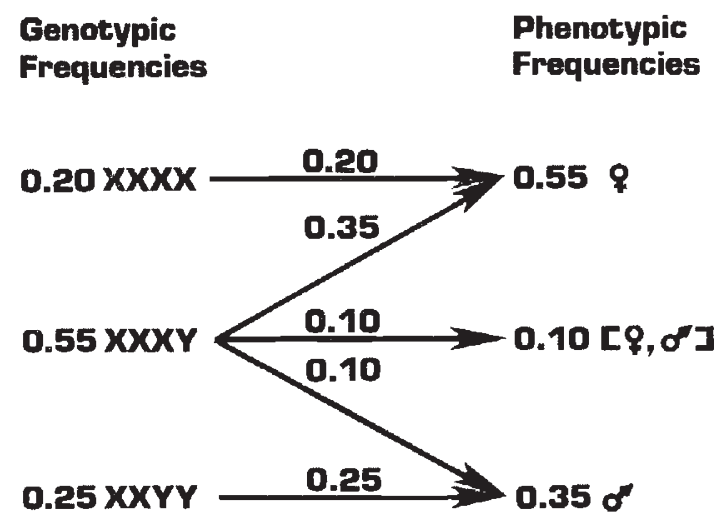

FIG. 1.-Apportionment of presumed genotypes to observed phenotypes during normal years (1972, 1974, 1975). During 1973 the apportionment would be radically different.

two assumptions. First, the mating combination $\mathrm{XXXX} \times \mathrm{XXYY}$ is more productive than the others. Data support this assumption since plants that do not change floral phenotype produce more gametes (E. D. McArthur, unpublished data). Second, the YY gamete is slightly less fit than gametes which contain an $\mathrm{X}$ chromosome or $\mathrm{X}$ locus or loci. This suggestion extends a principle proposed by Westergaard (1958). He postulated that the YY combination is inviable in all dioecious plant species in which heteromorphic sex chromosomes have been discovered. Additional support for this sex-determining mechanism is the relatively high proportion of nonviable gametes and poor seed germination in tetraploid $A$. canescens (Stutz et al., 1975, E. D. McArthur, unpublished).

A. canescens is being grown for seed production (Van Epps, 1974, 1975). Cloning consistently high-yielding pistillae bushes would seem to be an advantageous and safe practice for seed production. Since these plants are apparently stable in sex expression.

The sex-determining mechanism which I have suggested, although speculative, allows a consistent interpretation of available data from the half-sib family and natural populations.

Acknowledgments.-Federal funds for wildlife restoration were provided through Project W-82-R. G. A. Van Epps of the Utah Agricultural Expcriment Station's Snow Field Station provided the climatological records.

\section{REFERENCES}

ALDON, E. F. 1973. Revegetating disturbed areas in the semi-arid Southwest. $\mathcal{F}$. Soil and Water Cons., 28, 223-225.

AMCHEM PRODUCTS, INC. 1971. Fthrel ${ }^{\circledR}$ plant growth regulator crop response data. Technical service data sheet 2/71. Anchem Products, Inc., Ambler, $\mathrm{Pa}$.

AsHWOOD-SMTTH, M. J. 1970. Effects of low temperature on micro-organisms, plants, and cold-blooded animals. In Current Trends in Cryobiology, ed. A. U. Smith, pp. 5-42. Plenum Press, New York.

BASSETt, I. J., AND GRompton, c. w. 1971. In IOPB Chromosome number reports XXXIV, ed. A. Löve. Taxon, 20, 785-797.

Billings, F. H. 1934. Male gametophyte of Atriplex hymenelytra. Bot. Gaz., 95, 477-484. 
Blauer, A. C., Plummer, A. P., MCarthur, E. D., stevens, R., AND giunta, B. C. 1976 Characteristics and hybridization of important intermountain shrubs. II. Chenopod family. USDA For. Serv. Res. Pap. INT-177.

hall, H. M., AND clements, F. E. 1923. The Phylogenetic Method in Taxonomy. Carnegie Inst. Wash., Publ. 326.

hanson, C. A. 1962. Perennial Atriplex of Utah and the northern deserts. M. S. thesis. Brigham Young University, Provo, Utah.

Löve, A. 1969. Conservative sex chromosomes in Acetosa. In Chromosomes Today, ed. C. D. Darlington and K. R. Lewis, vol. 2. pp. 166-171. Plenum Press, New York.

MCARTHUR, E. D., AND PLUMMER, A. P. 1974. Improvement of wildland shrubs by selection and breeding-problems and progress. Abstr. Pap., 27th Annu. Meet., Soc. Range Manage., p. 17.

Plummer, A. P., mONSEN, s. B., AND CHRistensen, D. R. 1966. Fourwing saltbush, a shrub for future game ranges. Utah Dep. Fish and Game Publ. 66-64.

QUAGLIOTTI, L. 1972. Relazioni tra concimazione azotata, habitus vegetativo ed espressione sessuale nello spinaco " riccio d' asti". Sementi Elette, 18(2), 5-19.

RUDICH, J., HALEVY, A. H., AND KEDAR, N. 1972. The level of phyto-hormones in monoecious and gynoecious cucumbers as affected by photoperiod and ethephon. Plant Physiol., $50,585-590$.

SCHAFFnER, J. H. 1922. Control of the sexual state in Arisaema triphyllum and Arisaema dracontium. Am. F. Bot., 9, 72-78.

Sмrтн, в. w. 1969. Evolution of sex-determining mechanisms in Rumex. In Chromosomes Today, ed. C. D. Darlington and K. R. Lewis, vol. 2, pp. 172-182. Plenum Press, New York.

STARK, N. 1970. Water balance of some warm desert plants in a wet year. $\mathcal{F}$. Hydrol., 10, 113-126.

stutz, H. C., MElby, J. M., AND Livingston, G. K. 1975. Evolutionary studies of Atriplex: a relic gigas diploid population of Atriplex canescens. Am. F. Bot., 62, 236-245.

VAN EPPS, G. A. 1974. Shrub seed production-a potential enterprise. Utah Sci., 35, $21-23$.

VAN EPPS, G. A. 1975. Winter injury to fourwing saltbush. F. Range Manage., 28, 157-158. WESTERGAARD, M . 1958. The mechanism of sex determination in dioecious flowering plants. In Advances in Genetics, ed. M. Demerec, vol. 9, pp. 217-281. Acad. Press Inc., New York. WILDE, R. C. DE. 1971. Practical applications of (2-chloroethyl) phosphonic acid in agricultural production. Hortscience, 6, 364-370.

zUK, J. 1970. Structure and function of sex chromosomes in Rumex thyrsiflorus. Acta Soc. Bot. Poloniae, 39, 539-564. 